\title{
METHODS FOR ASSSESSING ENERGY EFFICIENCY OF GRAIN DRYERS
}

\author{
Janusz Nowak $\mathrm{a}^{\mathrm{a}^{*}}$, Wojciech Przystupa $\mathrm{b}^{\mathrm{b}^{*}}$ \\ a Department of Machinery Exploitation and Management of Production Processes, \\ University of Life Sciences in Lublin, Poland; Janusz.Nowak@up.lublin.pl, ORCID 0000-0002- \\ $8687-4483$ \\ b Department of Applied Mathematics and Computer Science, \\ University of Life Sciences in Lublin, Poland; Wojciech.Przystupa@up.lublin.pl, RCID 0000-0002- \\ 6423-8187 \\ *Corresponding author: e-mail: janusz.nowak@up.lublin.pl

\begin{tabular}{|c|c|}
\hline ARTICLE INFO & ABSTRACT \\
\hline $\begin{array}{l}\text { Article history: } \\
\text { Received: April } 2019 \\
\text { Received in the revised form: } \\
\text { May } 2019 \\
\text { Accepted: June } 2019 \\
\end{array}$ & \multirow{2}{*}{$\begin{array}{l}\text { The article presents an algorithm for calculating selected energy assess- } \\
\text { ment indexes for grain driers. Particular attention was paid to the con- } \\
\text { version of the equations obtained for the operating conditions of the } \\
\text { drying process into equations allowing the calculation of indexes for the } \\
\text { standard drying conditions. The indexes obtained allow a proper com- } \\
\text { parison of dryers operating in varied atmospheric conditions, as well as } \\
\text { humidity and temperature of the dried material. }\end{array}$} \\
\hline $\begin{array}{l}\text { Key words: } \\
\text { grain driers, } \\
\text { energy indexes, } \\
\text { standard conditions }\end{array}$ & \\
\hline
\end{tabular}

\section{Introduction}

The amount of energy used in the grain drying process is one of the main elements determining its effectiveness. The commonly used convection drying, which uses hot air as the drying medium, is a highly energy-consuming process (Dmytrów and Wróblewski, 1976; Gramatte and Häuser, 2004). In convection dryers, in which a significant amount of energy is lost along with the humid and warm air expelled, thermal efficiency sometimes does not exceed 50\% (Peroń et al, 2008, Billiris and Siebenmorgen, 2014; Billiris, 2013). A new generation of high-capacity dryers, made available to agricultural producers and purchasers storing cereal grains and rape seeds in the last decade, offers thermal efficiency of over $80 \%$ (Schwick, 2015a, b; Dokumentacja, 2016). Comparing driers based on energy efficiency indexes calculated directly from the test results obtained under different operating conditions (initial and final humidity of the grain, parameters of atmospheric air) is difficult, and doesn't provide objective conclusions (Agricultural, 1997, 2001; Walczak, 2007; Schwick, 2015c). In German research (Schwick, 2014, 2015a, b, c, 2017), calculations were made for strictly defined drying conditions, called standard, which determine stipulated values: initial and final humidity of the dried grain, temperature, relative humidity and atmospheric air pressure. 
The paper attempts to develop an algorithm for calculating selected energy indexes, based on the results of research for the Eco Dry STKL-05/02 grain dryer, made by a German company Bühler GmbH (Schwick, 2015b). Using the algorithm, energy indexes for both operating and standard grain drying conditions were calculated and later compared with the indexes included in the German report (Schwick, 2015b).

\section{Characteristics of the Eco Dry STKL-05/02 dryer}

The dryer Eco Dry STKL-05/02 was designed for drying freshly collected, loose and purified damp grain, with dust not exceeding the explosive rate of $160 \mathrm{bar} \cdot \mathrm{m} \cdot \mathrm{s}^{-1}$ (Documentation, 2016). In the case of stringent requirements regarding the cleanliness of the exhaust air, a centrifugal separator is used, allowing to reduce the dust content to below $200 \mathrm{mg} \cdot \mathrm{m}^{-3}$. The cleaned air can be expelled outside, or returned into the circulation. Another of the dryer's operation modes includes air recirculation and using an axial fan for discharging used air. Each model of the dryer can be equipped with surface burners for direct heating of the air with the stream of exhaust gas. Figure 1 shows a functional diagram of the Eco Dry STKL05/02 dryer.

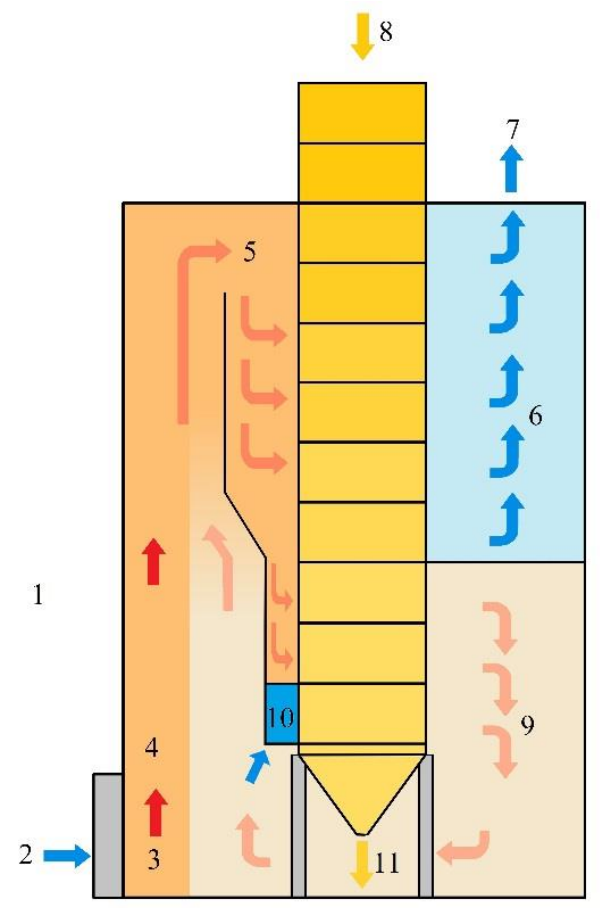

Figure 1. Diagram of Eco Dry STKL6-05/02 dryer by Bühler (based on Schwick, 2015b): 1 - outside air, 2 - air sucked in by an exhaust fan, 3 - gas burner, 4 -air directly above the burner, 5 - air supplied to the drying chamber, 6 - air after leaving the drying chamber, 7 - exhaust air, 8 -damp grain supply, 9 - air supplied by the recirculation fan, 10 - cooling air, 11 -dry grain 
Methods for asssessing energy...

\section{Algorithm for calculating the evaluation indexes of grain dryers}

Assessment indexes for the of grain driers, presented in the reports of the German Agricultural Society (Deutsche Landwirtschafts-Gesellschaft), were developed for operating and standard conditions of the drying process: change in humidity of the dried material from $35 \%$ to $15 \%$, air temperature $5^{\circ} \mathrm{C}$, relative humidity $80 \%$, air pressure $0.1013 \mathrm{MPa}$ (Schwick, 2014, 2015a, b, c, 2017).

Calculations necessary for the energy evaluation of dryers (for both operating and standard conditions) were made on the basis of the given equations (1-19). The meaning of the symbols appearing in the formulas is given in Tables 1 and 2.

Weight of damp grain $m_{m}$, dried in time $t$ was calculated according to the equation:

$$
m_{m}=m_{s} \frac{1-M_{s}}{1-M_{m}}, \mathrm{k}
$$

Drier capacity $\eta_{s}$ was expressed as the quotient of dry grain weight and drying time (in operating conditions), and calculated according to the equation:

$$
\eta_{s}=\frac{m_{s}}{3600 t}, \mathrm{~kg} \cdot \mathrm{s}^{-1}
$$

Drier capacity $\eta_{s s}$ (adjusted for standard drying conditions), was expressed as a quotient of dry grain weight and drying time, and calculated according to the equation:

$$
\eta_{s s}=\eta_{s} \frac{M_{u}}{M_{u s}}, \mathrm{~kg} \cdot \mathrm{s}^{-1}
$$

Drier capacity $\eta_{m}$ was expressed as the quotient of damp grain weight and drying time (in operating conditions), and calculated according to the equation:

$$
\eta_{m}=\eta_{s} \frac{1-M_{s}}{1-M_{m}}, \mathrm{~kg} \cdot \mathrm{s}^{-1}
$$

Drier capacity $\eta_{m s}$ (adjusted for standard drying conditions) was expressed as the quotient of damp grain weight and drying time, and calculated according to the equation:

$$
\eta_{m s}=\eta_{s s} \frac{1-M_{m s}}{1-M_{m}}, \mathrm{~kg} \cdot \mathrm{s}^{-1}
$$

Intensity of water evaporation from the grain $w$ under operating conditions of drying was calculated according to the equation:

$$
w=\eta_{m}-\eta_{s}, \mathrm{~kg} \cdot \mathrm{s}^{-1}
$$

The intensity of water evaporation from the grain $w_{s}$ under standard drying conditions was calculated according to the equation:

$$
w_{s}=\eta_{m s}-\eta_{s s}, \mathrm{~kg} \cdot \mathrm{s}^{-1}
$$

Specific heat consumption $E_{c}$ for evaporating water from the grain under operating conditions of drying was calculated according to the following formula:

$$
E_{c}=\frac{W}{w}, \mathrm{~kJ} \cdot \mathrm{kg}^{-1}
$$


The power of the dryer's heating unit $W$ was calculated from the equation:

$$
W=\frac{q \cdot V}{3600}, \mathrm{~kW}
$$

Specific heat consumption $E_{c s}$ for evaporating water from the grain under standard drying conditions was calculated according to the following formula:

$$
E_{c s}=E_{c}+E_{c z}+E_{c p}, \mathrm{~kJ} \cdot \mathrm{kg}^{-1}
$$

Adjustment of $E_{c z}$, due to the initial temperature of grain, which varied from the temperature set for the standard drying conditions during the tests, was calculated according to the equation:

$$
E_{c z}=\frac{C_{k} \cdot \eta_{m s}\left(T_{a}-T_{s}\right)}{w_{s}}, \mathrm{~kJ} \cdot \mathrm{kg}^{-1}
$$

However, it should be added that equation (11) applies only if the temperature of the grain supplied to the dryer is equal to ambient air temperature during drying.

Adjustment of $E_{c p}$, due to the ambient temperature of air, different from the temperature set for the standard drying conditions during the tests, was calculated according to the equation:

$$
E_{c p}=\frac{Q\left(i_{a}-i_{s}\right)\left(1+Y_{a}\right)}{3600 \gamma_{a} \cdot w_{s}}, \mathrm{~kJ} \cdot \mathrm{kg}^{-1}
$$

Enthalpy of $1 \mathrm{~kg}$ of dry air and $Y_{a} \mathrm{~kg}$ of water vapor contained therein was calculated according to equations (13) and (14). Average specific heat of dry air at temperature $T_{a}$ and $T_{S}$ was adopted at $1.005 \mathrm{~kg} \cdot \mathrm{kg}^{-1} \cdot \mathrm{K}^{-1}$, water vapor at $1.86 \mathrm{~kg} \cdot \mathrm{kg}^{-1} \cdot \mathrm{K}^{-1}$, and the heat of water evaporation at $0^{\circ} \mathrm{C}$, at $25001 \mathrm{~kg} \cdot \mathrm{kg}^{-1}$ (Strumiłło, 1983).

$$
\begin{aligned}
& \left.i_{a}=1,005 \mathrm{~kJ} \cdot \mathrm{kg}^{-1} \cdot \mathrm{K}^{-1} \cdot T_{a}+Y_{a}\left(1,86 \mathrm{~kJ} \cdot \mathrm{kg}^{-1} \cdot \mathrm{K}^{-1} \cdot T_{a}\right)+2501 \mathrm{~kg} \cdot \mathrm{kg}^{-1}\right), \mathrm{kJ} \cdot \mathrm{kg}^{-1} \\
& i_{s}=1,005 \mathrm{~kJ} \cdot \mathrm{kg}^{-1} \cdot \mathrm{K}^{-1} \cdot T_{s}+Y_{a}\left(1,86 \mathrm{~kJ} \cdot \mathrm{kg}^{-1} \cdot \mathrm{K}^{-1} \cdot T_{s}+2501 \mathrm{~kJ} \cdot \mathrm{kg}^{-1}\right), \mathrm{kJ} \cdot \mathrm{kg}^{-1}
\end{aligned}
$$

Specific volume of atmospheric air $\gamma_{a}$ for the test conditions were calculated according to the formula given by Strumiłło [1983]:

$$
\gamma_{a}=22,4\left(\frac{1}{29}+\frac{Y_{a}}{18}\right) \frac{T_{a} \cdot P_{s}}{273 P_{a}}, \mathrm{~m}^{3} \cdot k g_{s p}^{-1}
$$

Water content in atmospheric air supplied to the heating unit of the dryer $Y_{a}$ was calculated according to the formula given by Strumiłło [1983]:

$$
Y_{a}=0,622 \frac{P_{s a} \cdot \varphi_{a s}}{P-P_{s a} \cdot \varphi_{a s}}, \mathrm{~kg}_{\text {wody }} \cdot \mathrm{kg}^{-1} \text { sp }
$$

Relative humidity $\varphi_{a s}$ was calculated using the formula that was developed using the Krischer method (Krischer and Kast, 1978).

$$
\varphi_{a s}=\varphi_{a} \frac{P_{a} \cdot P_{S}}{P_{t}^{2}},
$$


Methods for asssessing energy...

Specific heat and power consumption $E_{c-p}$ for evaporation of water from the grain under operating conditions was calculated according to the equation:

$$
E_{c-p}=\frac{W+W_{p}}{w}, \mathrm{~kJ} \cdot \mathrm{kg}^{-1}
$$

Specific heat and power consumption for evaporation of water from the grain under standard conditions was calculated according to the equation:

$$
E_{(c-p) s}=\frac{W+W_{p}}{w_{s}}, \mathrm{~kJ} \cdot \mathrm{kg}^{-1}
$$

\section{Results of the calculations, and their analysis}

Table 1 presents the results of measurements taken from the Eco Dry STKL6-05/02 dryer, which were the basis for calculating basic indexes for dryer evaluation. Table 2 presents the results of calculations included in the German research report (Schwick, 2015b), as well as own calculations based on the developed algorithm.

Table 1.

Results of the measurements taken from the Eco Dry STKL6-05/02 dryer, conducted by the

\begin{tabular}{|c|c|c|c|}
\hline Specification & $\begin{array}{l}\text { Position } \\
\text { in figure } 1\end{array}$ & Symbol & Value \\
\hline Weight of dry grain dried over time $(t, \mathrm{~kg})$ & 11 & $m_{s}$ & 29570 \\
\hline Mass fraction of water in dry grain, & 11 & $M_{s}$ & 0.129 \\
\hline Mass fraction of water in damp grain, & 8 & $M_{m}$ & 0.352 \\
\hline Specific heat of $\operatorname{corn}^{1},\left(\mathrm{~kJ} \cdot \mathrm{kg}^{-1} \cdot \mathrm{K}^{-1}\right)$ & 8 & $C_{k}$ & 2.475 \\
\hline Drying time, $(\mathrm{h})$ & - & $t$ & 12.05 \\
\hline Temperature of atmospheric air, $\left({ }^{\circ} \mathrm{C}\right)$ & 1 & $T_{a}$ & 8.3 \\
\hline $\begin{array}{l}\text { Temperature of atmospheric air under standard drying } \\
\text { conditions, }\left({ }^{\circ} \mathrm{C}\right)\end{array}$ & 1 & $T_{s}$ & 5 \\
\hline $\begin{array}{l}\text { Relative humidity of the atmospheric air } \\
\text { (dimensionless), }\end{array}$ & 1 & $\varphi_{a}$ & 0.87 \\
\hline $\begin{array}{l}\text { Relative humidity of atmospheric air under standard } \\
\text { drying conditions (dimensionless), }\end{array}$ & 1 & $\varphi_{a s}$ & 0.80 \\
\hline Atmospheric pressure, $(\mathrm{MPa})$ & 1 & $P_{a}$ & 0.992 \\
\hline $\begin{array}{l}\text { Atmospheric pressure at standard drying conditions, } \\
(\mathrm{MPa})\end{array}$ & 1 & $P_{S}$ & 1.013 \\
\hline $\begin{array}{l}\text { Atmospheric air pressure } \\
\text { at which the properties of saturated air are given }{ }^{2} \text {, } \\
\text { (MPa) }\end{array}$ & - & $P_{t}$ & 0.1 \\
\hline Hourly fuel consumption, $\left(\mathrm{m}^{3} \cdot \mathrm{h}^{-1}\right)$ & 3 & $V$ & 77.04 \\
\hline
\end{tabular}
DLG (Schwick, 2015b) 
Janusz Nowak, Wojciech Przystupa

\begin{tabular}{|c|c|c|c|}
\hline Specification & $\begin{array}{l}\text { Position } \\
\text { in figure } 1\end{array}$ & Symbol & Value \\
\hline Calorific value of fuel, $\left(\mathrm{kJ} \cdot \mathrm{m}^{-3}\right)$ & 3 & $q$ & 36000 \\
\hline $\begin{array}{l}\text { Hourly consumption of atmospheric air heated by the } \\
\text { heating unit of the dryer, }\left(\mathrm{m}^{3} \cdot \mathrm{h}^{-1}\right)\end{array}$ & 2 & $Q$ & 24800 \\
\hline Power consumed by the fan drive motors ${ }^{3},(\mathrm{~kW})$ & 2 and 9 & $W_{p}$ & 33.7 \\
\hline
\end{tabular}

${ }^{1}$ Obtained directly from the author of the report,

${ }^{2}$ Tables from the work by Strumiłło (1983),

${ }^{3}$ Average power consumption values during drying $t$

Grain dryers can be evaluated based on specific indexes (Strumiłło, 1983; Walczak, 2007; Kudra, 2012; Billiris et al., 2011; Billiris et al., 2014). Some of them are: specific thermal consumption related to the amount of water evaporated from the grain, and thermal efficiency, defined as the ratio of useful energy to total energy (heat and power) used in the drying process. For dryers operating periodically, useful heat is the heat used to evaporate water from the dried material. It is calculated as the product of evaporation heat and the mass of the evaporated water. If, on the other hand, dryers operating continuously are evaluated, calculations are made on the basis of the product of evaporation heat of water and its intensity of evaporation. In some research, an indicator is proposed called thermal efficiency, defined as the ratio of useful energy to total fuel combustion heat introduced into the air dryer (Walczak, 2007; Billiris, 2013; Schwick, 2015a,b,c).

Table 2.

Indexes for the Eco Dry STKL6-05/02 dryer evaluation from the Schwick report (2015b) and own calculations, based on the results of the tests listed in Table 1.

\begin{tabular}{|c|c|c|c|}
\hline \multirow[b]{2}{*}{ Specification } & \multirow[b]{2}{*}{ Symbol } & \multicolumn{2}{|c|}{ Source of calculations } \\
\hline & & $\begin{array}{l}\text { Schwick } \\
(2015 b)\end{array}$ & $\begin{array}{l}\text { Schwick } \\
\text { (2015b) }\end{array}$ \\
\hline Weight of dry grain dried over time $(\mathrm{t}, \mathrm{kg})$ & $m_{m}$ & 39750 & 39746 \\
\hline $\begin{array}{l}\text { Water loss in grain expressed as percentage for standard grain } \\
\text { drying conditions, }(\%)\end{array}$ & $M_{u s}$ & 20 & 20 \\
\hline $\begin{array}{l}\text { Water loss in grain dried in operating conditions, expressed as } \\
\text { percentage, }(\%)\end{array}$ & $M_{u}$ & 22.3 & 22.3 \\
\hline Power of the dryer's heating unit, $(\mathrm{kW})$ & $W$ & 769 & 770.4 \\
\hline $\begin{array}{l}\text { Intensity of water evaporation from the grain under operating } \\
\text { conditions of drying, }\left(\mathrm{kg} \cdot \mathrm{s}^{-1}\right)\end{array}$ & $w$ & 0.236 & 0.234 \\
\hline $\begin{array}{l}\text { Intensity of water evaporation from grain under standard drying } \\
\text { conditions, }\left(\mathrm{kg} \cdot \mathrm{s}^{-1}\right)\end{array}$ & $w_{s}$ & 0.231 & 0.236 \\
\hline Specific volume of atmospheric air, $\left(\mathrm{m}^{3} \mathrm{~kg}^{-1} \mathrm{sp}\right)$ & $\gamma_{a}$ & - & 0.819 \\
\hline Drier capacity calculated based on damp grain weight, $\left(\mathrm{kg} \cdot \mathrm{s}^{-1}\right)$ & $\eta_{m}$ & 0.917 & 0.916 \\
\hline $\begin{array}{l}\text { Drier capacity calculated on the basis of the weight of damp grain, } \\
\text { adjusted for standard drying conditions, }\left(\mathrm{kg} \cdot \mathrm{s}^{-1}\right)\end{array}$ & $\eta_{m s}$ & 0.992 & 0.995 \\
\hline Drier capacity calculated based on dry grain weight, $\left(\mathrm{kg} \cdot \mathrm{s}^{-1}\right)$ & $\eta_{s}$ & 0.681 & 0.681 \\
\hline $\begin{array}{l}\text { Drier capacity calculated based on dry grain weight, adjusted } \\
\text { for standard drying conditions, }\left(\mathrm{kg} \cdot \mathrm{s}^{-1}\right)\end{array}$ & $\eta_{s s}$ & 0.761 & 0.759 \\
\hline Correction of $\mathrm{E}_{\mathrm{cz}}$ due to the initial grain temperature, $\left(\mathrm{kJ} \cdot \mathrm{kg}^{-1}\right)$ & $E_{c z}$ & 34.9 & 34.44 \\
\hline Correction of $E_{\mathrm{cp}}$ due to the atmospheric air temperature, $\left(\mathrm{kJ} \cdot \mathrm{kg}^{-1}\right)$ & $E_{c p}$ & 115.8 & 113.68 \\
\hline
\end{tabular}


Methods for asssessing energy...

\begin{tabular}{|c|c|c|c|}
\hline \multirow[b]{2}{*}{ Specification } & \multirow[b]{2}{*}{ Symbol } & \multicolumn{2}{|c|}{ Source of calculations } \\
\hline & & $\begin{array}{c}\text { Schwick } \\
(2015 \mathrm{~b})\end{array}$ & $\begin{array}{c}\text { Schwick } \\
(2015 b)\end{array}$ \\
\hline $\begin{array}{l}\text { Specific heat energy consumption for evaporation of grain water } \\
\text { under operating conditions of drying, }\left(\mathrm{kJ} \cdot \mathrm{kg}^{-1}\right)\end{array}$ & $E_{c}$ & 3313.7 & 3292.31 \\
\hline $\begin{array}{l}\text { Specific heat energy consumption for evaporation of grain water } \\
\text { under standard drying conditions, }\left(\mathrm{kJ} \cdot \mathrm{kg}^{-1}\right)\end{array}$ & $E_{c s}$ & 3464.3 & 3440.43 \\
\hline $\begin{array}{l}\text { Specific power consumption for evaporation of grain water under } \\
\text { operating conditions, }\left(\mathrm{kJ} \cdot \mathrm{kg}^{-1}\right)\end{array}$ & $E_{p}$ & 142.80 & 144.02 \\
\hline $\begin{array}{l}\text { Specific power consumption for evaporation of grain water under } \\
\text { standard conditions, }\left(\mathrm{kJ} \cdot \mathrm{kg}^{-1}\right)\end{array}$ & $E_{p s}$ & 145.89 & 142.80 \\
\hline $\begin{array}{l}\text { Specific heat and power consumption for evaporation } \\
\text { of grain water under operating conditions, }\left(\mathrm{kJ} \cdot \mathrm{kg}^{-1}\right)\end{array}$ & $E_{c-p}$ & 3456.50 & 3440.71 \\
\hline $\begin{array}{l}\text { Specific heat and power consumption for evaporation } \\
\text { of grain water under standard conditions, }\left(\mathrm{kJ}^{\mathrm{k}} \mathrm{kg}^{-1}\right)\end{array}$ & $\mathrm{E}_{(\mathrm{c}-\mathrm{p}) \mathrm{s}}$ & 3610.19 & 3584.44 \\
\hline
\end{tabular}

Based on the results from the measurements taken from the Eco Dry STKL6-05/02 dryer (Table 1), and the above formulas, calculations of many indexes characterizing the operation of the dryer were made. They were then compared with the values obtained by Schwick (2015b). Data presented in Table 2 demonstrate that some of the calculated values differ slightly from the values presented in the German research report. This applies mainly to the intensity of evaporation of water from the grain under operating conditions of drying $w$ standard drying conditions $w_{s}$, specific heat consumption $E_{c}$ and $E_{c s}$, as well as standard consumption of power $E_{p}$ and $E_{p s}$. Value of the index $w$ from Schwick's calculations (2015) is slightly higher than the index $w_{s}$, while the results of own calculations indicate a different relation $\left(w=0.234 \mathrm{~kg} \cdot \mathrm{s}^{-1}\right.$, and $\left.w_{s}=0.236 \mathrm{~kg} \cdot \mathrm{s}^{-1}\right)$. In contrast, the opposite relations result from the specific power consumption - the value $E_{p s}$ from own calculations is smaller than $E_{p}$. This is the result of imprecise dryer performance test data, relating to both dry and damp material. For this reason, the evaporation rate of water from the dried material under standard drying conditions $w_{s}$ is smaller, despite the fact that the loss of water in grain dried in operating conditions constitutes $111.5 \%$ of the water loss under standard drying conditions ( $22.3 \%$ and $20 \%$, respectively). Specific heat energy consumption used for evaporation of water from grain under standard conditions $E_{c s}$ constitutes approx. 1.045 of the value of specific heat consumption used for evaporation of water from grain under operating conditions. This is the result of supplying to the dryer an additional amount of thermal energy contained in atmospheric air and dried corn grain, both with temperature higher than the ambient temperature under standard conditions $\left(8.3^{\circ} \mathrm{C}\right)$.). Results for dryer tests carried out in different atmospheric air conditions showed different proportions - the value of the indicator $E_{c s}$ is lower than the value of indicator $E_{c}$ (Schwick, 2017). Please note that the value of specific heat and power consumption $E_{(c-p) s}$ resulting from own calculations constitutes $99.29 \%$ of the value of the indicator reported in the Schwick report (2015). 


\section{Summary}

Comparing driers based on indicators calculated for operational drying conditions can not reflect the quality of their operation in terms of energy if both the ambient conditions as well as temperature and initial moisture of the grain are different. Standard conditions are used as a reference point, which are the basis for the calculation of energy indicators. The developed algorithm allows to calculate the basic indicators for the evaluation of operating and standard grain drying conditions of dryers. Based on the developed equations, the results of own calculations almost fully agree with the results presented in the German report. Minor differences may result from the adoption of slightly differing parameters of damp air in the tables available.

\section{References}

Agricultural grain driers - Determination of drying performance. Part 1: General. ISO 11520-1: 1997(E).

Agricultural grain driers - Determination of drying performance. Part 2: Additional procedures and crop-specific performance. ISO 11520-2: 2001.

Billiris, M.A. (2013). Measuring the energy required to dry rice in commercial rice dryers. Theses and Dissertations. Paper 726. University of Arkansans, Fayetteville.

Billiris, M.A., Siebenmorgen, T.J. (2014). Energy use and efficiency of rice-drying systems. II. Commercial, cross-flow dryer measurements. Applied Engineering in Agriculture, 30(2), 217-226.

Billiris, M.A., Siebenmorgen, T.J., Baltz, G.L. (2014). Energy use and efficiency of rice-drying systems. I. On farm cross-flow dryer measurements. Applied Engineering in Agriculture, 30(2), 205-215.

Billiris, M.A., Siebenmorgen, T.J., Mauromoustakos, A. (2011). Estimating the theoretical energy required to dry rice. Journal of Food Engineering, 107(2), 253-261.

Dmytrów, E., Wróblewski, S. (1976). Sprawozdanie z badań prototypu suszarni do ziarna SD 10. PIMR. Poznań.

Dokumentacja. Suszarnia kolumnowa EcoDry (ST). (2016). BA028PL0713.docx. Bühler GmbH Grain Logistics. Eichstätter Straße 49. 92339 Beilngries. Germany

Gramatte ,W., Häuser, S. (2004). Riela. Durchlauftrockner GDT 200. DLG - Prüfbericht 5360

Kudra, T. (2012). Energy performance of convective dryers. Drying Technology, 30(11/12), 1190-1198.

Krischer, O., Kast, W. (1978). Trocknungstechnik. Bd.1: Die wissenschaftlichen Grundlagen der Trocknungstechnik. Springer-Verlag. Berlin - Heidelberg - New York.

Peroń, S., Zdrojewski, Z., Surma, M. (2008). Suszenie ziarna jęczmienia w suszarce komorowo-daszkowej. Inżynieria Rolnicza, 5, 189-194.

Schwick, S. (2014). Allgaier Process Technology GmbH. Wälzbett-Trockner WB-T. Trockungsleistung und Energiebedarf. DLG - Prüfbericht $6230 \mathrm{~F}$.

Schwick, S. (2015a). RIELA ${ }^{\circledR}$ Karl-Heinz Knoop e.K. RIELA ${ }^{\circledR}$ GDT 4000 Umluft V continuous dryer -maize drying. DLG Test Report 6167.

Schwick, S. (2015b). Bühler GmbH. Eco Dry STKL6-05/02 continuous-flow dryer. Drying output and energy demand. DLG Test Report 6265 F.

Schwick, S. (2015c). Stela Laxhuber GmbH. AgroDry ${ }^{\circledR}$ MDB-XN 2/16-SB Continuous Dryer. Drying output and energy demand. DLG Test Report 6263 F.

Schwick, S. (2017). Stela Laxhuber GmbH. Durchlauftrockner AgroDry MDB-XN 2/17-SB. Trockungsleistung und Energiebedarf. DLG - Prüfbericht 6511. 
Methods for asssessing energy...

Strumiłło, C. (1983). Podstawy teorii i techniki suszenia. Wydawnictwa Naukowo-Techniczne. Warszawa. ISBN 8320404185.

Walczak, R. (2007). Metoda oceny energetycznej suszarek rolniczych. Inżynieria Rolnicza. Rozprawy habilitacyjne, nr 25. Krakow.

\section{METODA OCENY EFEKTYWNOŚCI ENERGETYCZNEJ SUSZAREK DO ZIARNA}

Streszczenie. W artykule przedstawiono algorytm obliczania wybranych wskaźników oceny energetycznej suszarek do ziarna. Szczególną uwagę zwrócono na przekształcenie równań otrzymanych dla warunków eksploatacyjnych suszenia do równań pozwalających na obliczenia wskaźników dla warunkach standardowych suszenia. Otrzymane wskaźniki pozwalają na właściwe porównywania suszarek pracujących w różnych warunkach otoczenia oraz różnej wilgotności i temperatury suszonego materiału.

Słowa kluczowe: suszarki do ziarna, wskaźniki energetyczne, warunki standardowe

Source of financing: Statutory activity 